\title{
Las Epidemias: ¿Se Mandan Solas?
}

\author{
PABLO A. VIAL C. ${ }^{1}$ \\ 1. Profesor, Facultad de Medicina, Clínica Alemana Universidad del Desarrollo. \\ Pediatra Infectólogo, Clínica Alemana de Santiago.
}

En Abril del 2009 se identificó en seres humanos un nuevo virus influenza, de origen porcino, en México, Estados Unidos de Norteamérica, Canadá, y luego en otros países. El virus fue caracterizado como un triple recombinante con genes de influenza porcina, humana y aviar, subtipo A (H1N1) ${ }^{1}$. El 29 de abril del 2009, la Organización Mundial de la Salud (OMS), declaró una alerta pandémica en su fase 5, lo que indicaba que el virus se transmitía efectivamente de persona a persona, en al menos 2 países del mundo. A fines de mayo del mismo año, el virus había sido identificado en más de cuarenta países, con un número de casos que globalmente superaba los 5 mil. El 11 de junio, la OMS elevó el nivel de alerta a fase 6 , indicando que en el mundo se ha iniciado una pandemia, con un virus que se transmite en forma efectiva y continua entre individuos $\mathrm{y}$ que se expande a todas las naciones.

En relación al comportamiento de la recién bautizada "influenza humana A H1N1", la Dra. Margaret Chan, directora de la OMS dijo "el virus escribe sus reglas y éste, como todos los virus influenza, puede cambiar las reglas, sin motivo ni razón, en cualquier momento".

En todos los ámbitos existe incertidumbre. La población general, los científicos y la comunidad médica se han llenado de interrogantes frente a un nuevo fenómeno biológico, epidemiológico y clínico, ante el cual sólo contamos con información preliminar, fragmentada e incompleta. Nuestra inclinación natural a basar las decisiones en evidencias se ve desafiada y las acciones médicas deben ajustarse a normativas cuidadosamente diseñadas como un plan de preparación de pandemia ${ }^{1}$, que deberán ajustarse en un proceso dinámico, en la medida que la epidemia devele su genio en la población y el virus su comportamiento clínico en las personas.

El fenómeno biológico se caracteriza por la aparición y propagación de un nuevo virus en la especie humana: influenza humano A (H1N1). La atención general de los científicos y epidemiólogos había estado centrada en una posible pandemia por un virus aviar, tipo A subtipo H5N1, de alta patogenicidad, que progresivamente se ha diseminado en el mundo en especies aviares. Este ocasionalmente se ha transmitido a humanos como zoonosis, circunstancias en la que se ha observado una letalidad mayor al $50 \%$.

El virus influenza humano A H1N1, tiene un origen diferente. Un virus similar a este, triple recombinante de virus porcino, aviar y humano, tri-continental (con genes de América, Europa y Asia) había circulado en poblaciones porcinas por cerca de 10 años, con infrecuente transmisión a humanos. Una nueva recombinación de este virus, cuyo origen geográfico no esta determinado, le confiere la capacidad de trasmitirse efectivamente de persona a persona ${ }^{2}$. Puede llamar la atención que un virus influenza H1N1, subtipo ampliamente difundido en nuestra especie, pueda producir una pandemia. Sin embargo la hemaglutinina 1 (H1) humana y la porcina han tenido una evolución genética diferente, y 
el repertorio inmunológico del rebaño humano no tiene familiaridad con este nuevo $\mathrm{H} 1 \mathrm{~N} 1$; o -al menos una buena parte de este- no han tenido contacto con este virus. Un trabajo reciente de sueros de la población obtenidos en estudios de vacunas indica que si analizan grupos de diversas edades, sólo un $30 \%$ de los mayores de 60 años tiene actividad neutralizante contra el nuevo virus ${ }^{3}$, lo que sugiere que la especie humana puede haber estado expuesta a un virus similar en el pasado no reciente.

El fenómeno epidemiológico tiene las características descritas para otras pandemias por virus influenza: a) la población joven se ve más afectada, tanto en las tasas de incidencia como en la severidad; b) el virus tiene mayor transmisibilidad que la influenza estacional, y c) la infección tiene un impacto diferente en distintas regiones. La descripción de las características epidemiológicas de la infección en México y Estados Unidos de Norte América (EE.UU) ${ }^{4,5}$, indican que sobre el $80 \%$ de los casos han ocurrido en personas entre 5 y 50 años, y sobre el $50 \%$ de los casos entre 5 y 18 años. Esto podría corresponder a un característico patrón de transmisión predominantemente entre escolares que luego se extiende a sus contactos intrafamiliares. En México se han notificado más de 100 muertes por la infección y el $68 \%$ de estas se produjeron en personas entre $20 \mathrm{y}$ 50 años. Respecto al aumento de transmisibilidad, datos preliminares de la actual pandemia han establecido una tasa de ataque secundaria entre contactos escolares y familiares de 30$40 \%$, tasa propia de virus nuevos, que encuentran una alta proporción de la población susceptible. Finalmente, tal como se ha observado en Chile y el mundo, distintas regiones se ven afectadas heterogéneamente en su incidencia y mortalidad. Este fenómeno es dependiente en factores geográficos, climáticos, sociales y hábitos y conductas de la población, así como las características propias de la infectividad y virulencia con que evoluciona el virus localmente ${ }^{6}$. El período de incubación de la infección es similar a la influenza estacional (promedio 3 días, rango 1 a 7 días) y para el período de transmisibilidad se trabaja con una definición operacional, desde un día antes del inicio de los síntomas hasta 7 días después, pendiente están los estudios de excreción viral propios para este virus. Epidemiológicamente las pandemias se caracterizan también por ondas sucesivas, en años consecutivos. Actualmente, no sabemos si la infección adquirirá mayor virulencia, si los infectados esta temporada estarán más protegidos en brotes posteriores.

La determinación de la severidad clínica de la enfermedad por el virus A H1N1 es el área en la que se han notado mayores falencias en el plan de preparación de pandemia de la OMS. Las diversas fases de alerta se orientan más hacia la extensión de la infección en el mundo y su transmisibilidad, que a la severidad de la infección. La población y los médicos no han podido establecer con claridad la relación entre cambios de fases en las alertas, con la "peligrosidad" del virus para la población. Las descripciones clínicas con que contamos, de la epidemia en EE.UU. y México ${ }^{4,5}$, indican que la mayor parte de las personas evolucionan con un cuadro de influenza de características similares a las de la influenza estacional (fiebre, tos, cefalea, mialgias, congestión nasal), con una mayor proporción de síntomas gastrointestinales (nauseas, vómitos, diarrea). Sin embargo, algunos pacientes (aproximadamente 1-2 de cada 1000 ), en su segundo a cuarto día de evolución, desarrollan un cuadro de compromiso pulmonar con distress respiratorio, insuficiencia renal y rabdomiolisis, con alta letalidad. Al menos la mitad de los pacientes con esta evolución tienen los factores de riesgo conocidos de infección severa por influenza, pero también incluye un porcentaje de pacientes sanos y jóvenes. Hasta ahora no se ha determinado un perfil clínico que permita diferenciar quién evolucionará a mayor gravedad. Sabemos también que la actual epidemia tiene una tasa de hospitalización mayor (2 a 9\%) que la influenza estacional. Es posible que esta tendencia a mayor hospitalización tenga relación a la alerta generalizada y en muchos casos corresponda a casos de fiebre de difícil manejo, hiperemesis y otras complicaciones no respiratorias. El diagnóstico de la infección se ha visto complicado por dos circunstancias; la primera es que la epidemia en Chile ocurre en otoño-invierno, período en el que este año hay un brote simultáneo de virus respiratorio sincicial y virus parainfluenza. Por 
lo tanto, el diagnóstico basado en el síndrome clínico (fiebre y síntomas respiratorio y de compromiso del estado general) no permite diferenciar, en menores de 5 años, la etiología de la enfermedad. En segundo lugar, el método de diagnóstico más ampliamente usado en el país, la inmunofluorescencia directa de secreciones respiratorias, tiene una baja sensibilidad (aproximadamente $50 \%$ ) para detectar las infecciones por el nuevo virus influenza, lo que se traduce en un bajo valor predictivo negativo (cerca del $45 \%$ de los resultados negativos) por IFD para influenza son positivos por biología molecularRt-PCR (basado en evaluación prospectiva de 150 muestras en Clínica Alemana de Santiago).

La evaluación de sensibilidad a antivirales en el CDC, Atlanta, USA, indican que el nuevo virus es sensible a oseltamivir y zanamivir y resistente a amantadita ${ }^{7}$. En Chile, las autoridades de salud, ante estas circunstancias y en la actual fase de la pandemia, recomiendan el uso de tratamiento con antivirales en los casos diagnosticados clínicamente en mayores de 5 años, y en los casos con factores de riesgo o aquellos confirmados por laboratorio en los menores de 5 años. Esta recomendación esta sujeta a cambios en la medida que se cuente con mayores conocimientos del espectro clínico de la infección, efectividad clínica, susceptibilidad del virus y efectos adversos de los antivirales.

\section{La epidemia ¿se manda sola?}

La incertidumbre inicial sugiere una respuesta afirmativa. La respuesta final depende de todos nosotros y estará determinada por la rapidez con la que podamos establecer estrategias preventivas y de tratamiento, efectivas y oportunas. Información, educación, buena higiene personal, distanciamiento social, tratamiento antiviral, vacuna: estrategias que requieren de una colaboración global y de priori- zación según su disponibilidad y oportunidad. Contamos con algunas ventajas respecto a pandemias anteriores: un sistema de salud mejor articulado, un plan de preparación de pandemia, vigilancia epidemiológica y virológica, tratamiento antiviral, antibióticos contra neumonías bacterianas secundarias, vacuna antineumocócica y mejor manejo del paciente crítico. Sin embargo, es claro que aún con todos estos avances, no hay ningún país que pueda evitar la transmisión de un virus pandémico.

Una última nota de precaución. En tiempo de influenza, no todo cuadro febril es influenza. $\mathrm{Si}$ bien las epidemias necesitan de acciones rápidas, nunca se debe descuidar el juicio clínico, la adecuada evaluación de cada paciente y la reflexión crítica de lo que estamos haciendo.

\section{Referencias}

1.- Plan Nacional de Preparación para una Pandemia de Influenza. Ministerio de Salud de Chile, segunda edición, 2007. www.pandemia.cl

2.- Belshe R. Implications of the emergence of a novel H1 influenza virus. N Engl J Med 2009; 360: 2595-7. (publicación electrónica, previa a su edición impresa)

3.- CDC. Serum cross-reactive antibody response to a novel influenza A (H1N1) virus after vaccination with seasonal influenza vaccine. MMWR 2009; 58: 521-4.

4.- Dawood F., Jain S y Novel Swine-Origin Influenza A (H1N1 virus Investigation team. Emergence of a novel swine-origin Influenza A (H1N1) virus in humans. N Engl J Med 2009; 360: 2605-12 (publicación electrónica, previa a edición impresa).

5.- CDC. Update: Novel influenza A (H1N1) virus infection-Mexico, March-May, 2009. MMWR 2009; 58: $585-9$.

6.- Miller M, Viboud C, Balinska M, Simonsen L. The signature features of Influenza pandemics-implications for policy. N Engl J Med 2009; 360: 2595-7 (publicación electrónica, previa a edición impresa).

7.- CDC. Interim Guidance of antiviral recommendations for patients with novel influenza A (H1N1) virus infection and their close contacts. www.cdc.gov/ H1N1flu/recommendations.htm 